\title{
A Review of Difference of Opinion between Constitutionalist and Legitimist Olama (Scholars)
}

\author{
Hamidreza Esmaeili ${ }^{1}$ \\ SeyedJavadEmamJome Zadeh² \\ Hossain Masoudnia ${ }^{3}$
}

Alireza Aghahosseini ${ }^{4}$

\begin{abstract}
${ }^{1}$ Ph.D. Student of Political Sciences, University of Isfahan, hamidsmaelli@gmail.com ${ }^{2}$ Associate Professor \& Faculty Member of Department of Political Sciences, University of Isfahan, javademam@yahoo.com

${ }^{3}$ Assistant Professor, Faculty Member of Department of Political Sciences, University of Isfahan, hmass2005@yahoo.com ${ }^{4}$ Associate Professor \& Faculty Member of Department of Political Sciences, University of Isfahan, alireza.aghahosseini@gmail.com
\end{abstract}

\section{Doi:10.5901/mjss.2016.v7n2s1p164}

\begin{abstract}
There are two general theoriesin explaining the difference of opinion between theConstitutionalist and Legitimist scholars (Olama) in the history of ideas in the Constitutional period. Some researchers regard the main point of differencebetween two groups as their differentunderstanding of religion and Islam, and have founded the historicism of their own political thinking on this premise. On the other hand, some researchers have considered the reason for this difference not in different understanding of the religion but in the differentt views on the Constitutionalism. In other words, what made a distinction between two groups of the Constitutionalists and Legitimists was different interpretations and readings of the Constitutionalism rather than those of the religion. By the adoption of the first view, the current article seeks to analyze intellectual difference between the two groups based on the texts remained from these scholars.
\end{abstract}

Keywords: Clergy; Political Thinking; Iran Contemporary History; Constitutionalist and Legitimist

\section{Introduction}

Constitutional Revolution in Iran took place in July 1906 by a decree issued by Mozaffar ad-Din Shah. In this movement, different social groups were involved, which one of them was clerics. The clerics must be considered as the most important social and political actors of Iran in the period. However, after a short time, a difference happened between these two supporting groups of the Constitution, and they were divided into the Constitutionalist and Legitimist Scholars.During the dispute over the Constitutionalism, a considerable body of literature were composed by some clerics on defending or refuting it. Utilizing jurisprudential citations and proportional to the religious culture of the day, most of the literature seeks to presents religious views about the Constitution, type of government, and religious policies. The adoption of the constitutionalism by the scholars despite using jurisprudential/theological paradigms was not easy, and it must be explained mainly through theology and juridical methodology.Constitutionalists' systematic method would allow them to support it. This is because thejurisprudential teachings built upon authoritativeness of reason and ljihad right made their mind ready for the adoption of social evolutions (Enayat, 1986: 28). On the other hand, the constitutionalist scholars who had already supported the movement also were Islamic Jurisprudents. Now the question is this: in spite of the fact that both groups were "jurists", why they adopted different position against the Constitution?

In this article analytical method is used because an important part of the disagreement between the constitutionalists and legitimists is rooted in disagreement about description and understanding of the concepts. Therefore, the cause of the disagreement won't be cleared if the key concepts are not analyzed.

Primarily, we had better explain, by analytical method, which meanings of the new concepts were considered by the two groups at the age of constitutional? Accordingly, we can find out the point of both disagreements and agreements between constitutionalists and the legitimists.

The aim of this article is-according to these descriptions- strengthening of a view point which claims that the original cause of disagreement between both constitutionalists and legitimists is not religious concepts, but new concepts; specially the concept of "constitutional". 


\section{Ideas and Political Positions of the Constitutionalist Scholars}

\subsection{Explaining the Constitutionalismwith religious literature}

These scholars would consider theConstitutionalism as a means to limit the power of the court and reduce illegitimacy, which they thought that these two negative factors were indispensable in the government institution, thus democracy was relatively accepted in the historical process of the theory of Shia predominance (Derakhsheh, 2005: 78). Other purposes of the scholars' support of constitutionalismwas to protect Islam and its quantitative and qualitative expansion through utilizingmodern intellectual achievements. For instance, Haji AsadullahMamaghani's idea was built upon the principle that to preserve Islam, the current science should be learnt from the Westernersand employed against themselves (Abadian, 1995: 83 \&107).The same point can be deducted from the treatise "AndarzNameh" by AkhondLorestani or from the book entitled "Moghim\&Mosafer" (Resident and Traveler) by NourollahEsfahani (Esfahani, 1948: 127). Another reason for the experts' support of the Constitutionalismcan emanate from the categorization of governments conducted by Shaikh EsmaeilMahalati. He divided governments into three categories including the Holy Imam's State, absolute despotic monarchy, and limited and contingent government, and he believed that the Constitutionalismis not in line with absolute despotic monarchy (Kamali, 2002: 136).

Attempts made by followers of 'School of Najaf'(as an institution found by AkhundKhorasani in 1935 in Najaf) in the Constitutional movement was built on the premise that Sharia does not oppose politics, and the principles of many political phenomena such as majority of votes, people's political participation, freedom, equality and justice are compatible with Islamic law. Their concern was to introduce the political system of Islam as an anti-despotism institution and consistent with the Constitutionalismin every possible way. Therefore, when Khorasani observes that the viewpoint of some of the Constitutionalists is in sharp contrast to that of the Constitutional scholars, he adopts an opposing stance, and in his interpretation of the Constitutionalismstates: "the Constitutionalismof eachcountry means the commitment of royal administrations and government departments to avoiding the encroachment ofthe specified limits and regulations, according to the official religion of the country" (Namdar, 1997: 161).Although he did not express his beliefs on the characteristics of an eligible ruler and his election based on religious criteria, he considers Islam religion as the basis for the legitimacy of the ruling system and the relevant regulations and laws. He states that the Constitutionalismcan be a good conduit for further dissemination of the religion in the society, and a good instrument for alleviating the recalcitrance and despotism of secular rulers. In addition, he believes that social forces and political institutions are required to govern the people and society based on respect for and observance of these values (Namdar, 1997: 148-161).

Unlike Akhond, Sheikh Reza Dehkharghani in a treatise called "TozihMaram" defined the Constitutionalismonly in terms of the electability of the rulers, and did not elaborate on other aspects. He believed that in case of the electability of the state and the people's freedom of choice, the people's vote will lead to the election of eligible andeffective representatives. Therefore, support of the Constitutionalismis the same support of more eligible persons to occupy the position of the presidency over people, which is compatible with Shia (Abadian, 1995: 108).

Among the debatable issues which were discussed among the Constitutional scholars was "the separation of powers". Most of the Constitutional scholars such as Emad al-OlamaieKhalkhalistated that: "The task and the responsibility of the nation's representatives is the enforcement of law, and the main duty of religious and judicial courts is and the differentiation and discrimination of laws and regulations, and the task incumbent upon the Muslims is the execution of such laws. And these three powers should be always disconnected from each other" (Abadiyan, 1995: 94).About the relationship between theMajliss'scustomary (Orfi) law and Sharia law, the constitutional scholars made a distinction between general and specific or religious and customary(Orfi), and believed that the philosophy underlying the Constitutionalism encompasses popular issues and does not molest Sharia. Mullah Abdul al-RasoolKashani believed that legitimism does not refute adherence to creed and beliefs. Thus, if a prominent figure such as Haj Aqa Noor Allah Isfahani believed that: "the Constitutionalismis the same Islam, and Islam is the same Constitution, and Constitutionalism is Islamism" (Esfahani, 1948: 17), the reason was that he had realized that the Majliss's legislation does not have adverse effects on Sharia laws, and they are more executive ones. Kashani stated that Islam laws are not subject to any change, its lawful is lawful and its unlawful is unlawful to the day of the Resurrection. He even believes that the WesternConstitutionalismhas used Islamic Law as a model, because following the failure in the Crusades, "after a little while they came to the conclusion that the key to the victory of Muslims was nothing other than the constitutional law and Islamic Sharia which were built upon unity, the brotherhood, justice and equality" (Esfahani, 1948: 125).

Nurullahlsfahani's conception ofthe Constitutionalismis against despotism, and is consistent with his opinion on despotism "an authoritarian person states that the enforcement of the divine law depends on the wishes and desires of ruler" (Esfahani,1948: 54). In his view, the Constitution even can contribute to the implementation of Islamic law, and 
Shah (the King) cannot avoid enforcing the divine law in some cases optionally. According to Isfahani, the Constitutionalismcan effectively increase the social power of the scholars, push the society further toward spirituality and religion, alleviate the tyranny of despotism, and shorten the hands of despotism by enhancing the national development.

The writings of SeyedSalarias a Constitutionalist do not advocate the Constitutionalism in which the people's representatives have legislative powers and the separation of powers is carried out based on the same style of Western systems, and freedom of thought surpasses religious beliefs. The fundamental ideals of SeyedSalari was to establish justice and destruction of oppression. In his opinion, justice was the fact that the king has not the right to oppress the peasants. Therefore, his definition did not encompass equality among citizens. He defined oppression as cruel actions and ravage and killings of defenseless people applied by government officials (Abadian, 1995: 112-114).

Lari believed thatthe Majlisshas legitimacy when its president is "a fully qualified equitable jurist", and the representatives are also among the just persons in the society. In his opinion, the Mjliss's president has an irrevocable ruling power and is the sole executor of the rules. Lari enumerated the limits of authority of the Majissinto two domains: firstly, "enforcement of legitimate rules and divine penalties and affirming Friday Prayer, Jihad, performance of obligations", and secondly, "specifying general regulations and public decrees (MasalehNo'eiya") including dismissal, punishment and confinement, etc. (Lari, 1946: 4). From the viewpoint of SeyedLari, "OmorHasbieya" (benevolent actions which requires a qualified religious jurist or his representative) whichthe public does not have right to intervene in them, not only encompasses some areas such as monitoring estates of an anonymous and unknown owner, guardianship of orphans and endowment, but also covers the government.No one has the right to oppose fully qualified jurisprudent, unless "some eligible Muslim figures" affirm that the jurisprudent has committed debauchery and betrayal. From Lari's perspective, the only body fully qualified to establish the Majissand to assign and elect the representatives and the president is Islamic Judge or 'Mojtahed'.It is possible if "legitimate fully qualified ruler" announces it as lawful. Regarding the nature of the Majiss's law and freedom of thought, he believes that "there is no legitimate body and council, strategy and vote, and no reason and rational and sentient cannot be qualified except for Islamic rulers, jusrsts and legislators" (Lari, 1945: 4 \& 5).

Among the Constitutional scholars,SeyedMohammad Tabatabai, due to multiple trips to Russia, meeting with various politicians and linkages to the Iranian secret society, had a different opinion onthe Constitutionalism(Haeri, 1985: 102-106). His comments encompassed the concept of nationality in a modern sense, and he had a favorable opinion about the new schools. Influenced by the philosophy of the Western democracyand 'general will' of Rousseau, he believed that the king isthe one appointed by the nation, and is able to recruit soldiers and collects tax to stop the oppression of the subjects to each other. Therefore, if the King fail to accomplish his tasks, subjects must refer to another person. According toTabatabai, only those who are master at the new science can fathom such implications (Kermani, 1983: 449-450, vol. 1). He predicted that with the formation of the Constitution, the authority of the clergy will be reduced (Kasravi, 2537: 76; vol. 1). However, he but no affirmation about the separation of religion and political power (Kamali, 2002: 132).

\section{2 "Tanbih al-Omma\&Tanzil al-Mellah" as the most prmonient work of the Constitutional scholars}

Among the books left by the Constitutionalists, "Tanbih al-Omma\&Tanzil al-Mellah" by Ayatollah Mohammad Hossain Naeini is the most important work of the Constitution. In his book, Naeini regards "religious dictatorship" on a par with "royal dictatorship" and he points to the Qur'anicverses and hadiths that commands human to liberation from obedience of nothing other than God and "arbitrary rule of oppressive rulers". Here, he has regarded "devotional servitude of Allah" as help mankind into freedom from bondage, and as the most important mission of the Prophets sent by God Almighty. According to the same Qur'an verses and hadiths, compliance with arbitrary domination of unjust rulers is oppression to ourselves and even is considered to be idolatry (Naeeni, 1982: 27-28).Naeini argued that humans, except the infallibles and righteous men, are avaricious and in an inherent desire for achieving power. Therefore, there should be a "legal power" in the community to protect freedom and justice. He calls such power as "GhovehMasduda" (Blocking Power). In his view, when the Islamic society is deprived of the guardianship of the holly Imam and a fully qualified righteous person, nation is naturally faced by two types of government: despotic ruling (Tamlikiyeh) and Constitutional ruling (Velayatieh) which is based on the public interests, and disseminates participation, freedom and equality through limiting the power. He states that theConstitutional government is based on two principles: first, the enactment of the Constitutionalismwhich only religion and faith can limit it, and second, the formation of "Masdoudiyeh Body" composed of the national intellectuals which are sufficiently knowledgeable on international law and the political requirements of the age, and the "National Consultative Parliament is their authorized body" (Naeini, 1982: 13-16).

Naeini emphasizes that the ideal example of Shia government can be realized only by the presence of the infallible 
Imam, and he introduces a relatively qualified alternative which is confirmed by the Islamic leaders as well. This government is the government of fully qualified Islamic jurist as the representative of Imam, which wisdom and Sharia dictate that in case of lack of fertile grounds for the establishment of the ideal Islamic government, fully qualified jurist can act based on the holy hadith "What cannot be completely attained, should not be completely left" (ما لايدرك كله لا يُترك 48 ) كلد and some part of this obligation can be revived through the Constitutionalism (Naeini, 1982: 36 \& 48).

Another alternative by which Naeini seeks to prove the Constitutionalismfrom the perspective of Islam is council and the public participation of Muslims in determining their own government andruler. By defining participative indicators such as election, majority and representation within the framework of Islamic resources, Naeini attempts to point to the fact that the Westerners owe to Islam in these areas. In addition, by citing some Qur'an verses on consultation and the emphasis of Prophet of Islam on compliance with majority vote, Naeiniestablished the legitimacy of the formation of councils (Naeini, 1982: 53).

Given the above instances, and Naeini's emphasis on the fact that the Constitutional government should be established under the authorization ofMojtahed's, it is clear that one of his fundamental objectives in advocating the Constitutionalismwas maintaining the current size of the Islamic government as a council and to safeguard Islam and Muslims. Therefore, he states that the responsibility of the Majliss's representatives is to do the same things that Islamic jurists would do if they had opportunity to govern Islamic state. Therefore, along with knowledge of international politics and the financial health, Naeini argues that representatives should be ardently concerned about religion and independence country. According to him, if the jurists were rulers in the community, would do their best to accomplish three tasks: a fair and just collection and expenditure of the tax, legislation in areas where there is no divine principal, and separation of powers (Naeini, 1982: 50 \& 105).Introducing Islam laws as fair and equitable, Naeini presents only an egalitarian definition of their implementation, thus he investigates equality and justice in terms of execution rather than legislation (Naeini, 1982: 61). The importance of this issue is because the most important reason for the Constitutionalists' disagreement with the Constitutionalismwas that they believed that the new system will lead to secular legislation, while legislation is only for God.Naeini attempted to deal with such criticism. However, along with the Constitutional scholars, he also states that legislation should be performed only by a "holy legislator" and others cannot formulate laws arbitrarily and in sharp contrast to the divine laws (Naeini, 1982: 137).

\section{Political Opinions and Positions of the Legitimist Scholars}

\subsection{The positions of the constitutionalists and their criticism on the Legitimists}

Although the Legitimists had shared opinions with the Constitutionalist scholars in terms of the theological/legal paradigm and had a shared objective in mind, i.e. the formation of the Majliss "built upon enjoining the good and forbidding evil, eradication of oppression and protection of Islam and public interests" (Kasravi, 2537: Vol. 1: 431), when the Legitimists observed that the Constitutionalists have lost the process of the Constitutionalism, they first tried to do reformation and as they failed to do, so they remained silent in the face of Mohammad Ali Shah's suppressions. The biggest criticism of the Legitimists scholars against the Constitutionalists was that they did not pay attention to the guarantee of execution of the Constitutionalism(Najafi, 1999: 164). Mohammad Hossein Tabrizione of the Legitimists writes: "AMajliss whose commandments is not opposed to the divine law can be the subject of consensus between the Shah and two groups of scholars... However, the issue that has caused dissent in this regard is that some advocates of the Majliss including scholars, lawyers and peasants believe that the concluded the Majliss is the same intended and desirable one, but the current Majiss is a body other than the promised one" (Tabrizi, 12).

In this context, by the attempts made by the Legitimists and initiatives of Sheikh FazlollahNouri, Article II of the supplement to the Constitution was ratified. This supplement stipulated that the clergy and scholars can oversee the acts ratified by the Majliss. Although Sheikh Fazlollah first was a constitutionalist, after the victory of the Constitutionalismand at the time of the formulation of the Constitutional Law, when he realized that some of his companions such as TaqiZadeh are inclined to the West so he separated from them, and was assigned as the leader of the Legitimists such as SeyedKazemTabatabaeiYazdi, MirzaHasanMojtahedTabrizi, and MollaGhorban Ali Zanjani (Kasravi, 2537: 358-381, vol. 1). Ahmad Kasravi that were closely associated with secular Constitutionalists writes that: "I can affirm that they demanded 'European constitutional law'", and then he adds: "as the Constitutional scholars were not completely familiar with the meaning of the Constitutionalismand the propagation of European laws, so they insisted on it" (Kasravi, 2537: 287-325, vol. 1).

Kasrawī and Sheikh Fazlollah, from two different perspectives, regarded the publication of the western-oriented modernist newspapers as the cause of division and controversy among scholars (Kasrawī, 2537: Vol. 1: 288).In this 
regard, Sheikh Fazlolallah wrote: "The origin of these disturbances was newly-emerged tendencies which imitated [the western] neighbors. [they deceived all] including me... [but] when the project was started to initiate, I observed that some people who were once really healers to some diversions play roles in this devious way. Some delusional words were heard from them. Then, new acts were done by them, and they attempted to elect rulers and representatives based on majority vote. However, this was also overlooked. Finally, they sought to formulate constitution and legislation" (Madani, 1990: 137-138, vol. 2).

To recognize the Constitutionalismand the relevant ideals such as freedom and equality and the parliamentary authorities, the Legitimists paid attention to Western-oriented secular intellectuals rather than presenting their own interpretations, and believed that the Constitutionalismis the same thing that the Western-oriented intellectuals say not what Constitutionalists seek to achieve: "if thousands of Mojtaheds write that the Majliss is built upon 'enjoining good and forbidding wrong' and the implementation of divine law and help the oppressed and protection of Islam and Muslim interests, you will see that it is not so, and the process aims only to counter the influence of 'enjoining good and forbidding wrong'. This is because the foundation of such Majliss is built upon [secular] liberation and neglect of Islam and Mojtaheds" (ZargaryNejad, 1998: 183).

The Legitimists recognized that after the issuance of the Constitutionalismdecree, the body assigned to regulate the Statute is composed of some Western-oriented secular intellectualssuch as Sanie Al-Doleh, Mokhber al-Saltaneh, Hasan and HosainPirnia, and MirzaHasanMoshir al-Doleh who used the western laws for enacting the Statute. Therefore, unlike the Constitutionalists, the Legitimists were not optimist about the situation and came to the conclusion that accomplishing their religions objectives is highly unlikely (Amiri, 2003: 105-107). The author of the treatise "Tazkara alQafel and Ershad al-Jahel" who is anonymous and some have attributed that to Shaikh Fazlollah (Zargarinejad, 1998: 172), addresses the Constitutionalists and writes that: Western-oriented secular intellectuals "had the ascendancy of the Majliss, and [scholars] were marginalized, and even were not able to resist such notables even in one case... the western-oriented intellectuals aimed not to act based on Holy Quran and to be honest to public and they did seek refuge in the unbelief [the British Embassy]. How can we believe that the profanity is going to be advocate of Islam...? If the main intention was to protect Islamic legislation, they would not say the Constitutionalismis our supporter, and we do not let them deviate the Legitimism as well...So far, they have mentioned Sharia and Islam to only appease us... you must know that the real Constitution happens when some representatives elected by the public are assembled in the Majliss and they are able to issue decrees on the affairs of the country, and to formulate effective laws based on the requirements of the time and in an independent manner, and in accordance with the majority's interests and irrespective of agreement or disagreement with the holy Sharia" (Zargarinejad, 1998: 182).

The Legitimists did not consider the Constitutionalismmerely as an assembly for them, it was a cultural movement and the consequence of anti-religious corruptions manifested in the writings of the Western-oriented secular intellectuals. One of the clerics of the day state in this regard that: "From the first day of the inauguration of the Majliss, some newspapers and night letters (ShabNameh) are being published which mostly denounce the Islamic scholars and clerics and Islamic rules, and their emphasis is on interference in the divine religion....and they claims that the rules which have been formulated since 1300 years ago should be adapted to all the circumstances and requirements of today, such as the permissibility of the intoxicants, promotion of bawdyhouses, opening of girls' education schools and elementary school for maidens, and expenditure of funds on the construction of plants and illegal affairs rather than on mourning for the Divine Infallibles and visitation of their holy tombs...And derision of the Muslims for their holy convictions, and refuting the sayings of the Prophet Mohammed, and claiming that today's foreign philosophers are more knowledgeable and wise than the prophets and also the Occultation (or the messianic notion of the advent of the Mahdī) is just superstition" (Kasravi, 2537: 418, vol. 1).

What deteriorated the concerns of the Legitimists was the newly-composed content of the Constitution. The writings showed that the Constitutionalismin not in line with the strengthening of the authority of the religious values and the clergy. In one of the writings of the western-oriented secular intellectuals, it had been stated that: "all legal provisions and articles can be altered including the articles on the legitimacy of the Sharia". They also criticized the eighth Article which would articulate that "people of the country will be equal in terms of the state law" (Kasravi, 2537, 315-316, vol. 1). Unlike the Constitutionalist, the Legitimists believed that this principle is in sharp conflict with many jurisprudential issues, e.g. men and women shall not have equal rights, and Muslim and infidels are not the same (Madani: 1991: 140, vol. 2).

The same difference can be seen in the area of liberation and freedom. The Constitutional scholars believed that freedom is limiting royal power, while the Legalists had another interpretation and believed that most of the materials which now are published against Sharia in the books and newspapers are the aftermath of such freedom. For example, Sheikh Fazlollah believed that: "if there was not freedom that maleficent man [Abdul'RahimTalibovTabrizi] did not write that the law of the Quran today is not enough for us [and] we must forge thirty thousand sentences to suffice our own 
today's affairs" (Zargrinejad, 1999:180).

The Legitimists agreed the Majliss that would limit the monarchy through "constitution and internal regulations and guidelines" (Torkaman, 1983: 195, vol. 2). The main reason for their opposition to the legislation in the Majliss was that they would anticipate that with such an approach adopted by Western-oriented secular intellectuals and reflected in their media, "they intend to turn Iran's Majliss into Paris Parliament" (Rezvani, 1983: 31). Thus, the western-oriented intellectuals gradually abolish Sharia law, and such law is replaced with humanitarian law in the same European style. So they argued that "[at the beginning] the Majliss aimed to formulate laws only on administrative, court, and state affairs in order to limit the king and the royal body, and curtail any oppression, violation and encroachment, [however] today we can see that the legal laws of the European Parliament are taken into account and implemented in the Majliss" (Kasravi, 2537: 421, vol. 1).

\subsection{Sheikh Fazlollah writings}

Among the Legalists, Sheikh FazlollahNouri is more famous than others. His written legacy is some short pamphlets on the review of the Constitutionalism and opinion and the positions held by the Legitimists. However, SheikhFazlollahNouri would consider himself as constitutionalist and advocate of an Islamic Majliss built upon religious beliefs and the authority of the jurists, yet he believed that such objective has not yet accomplished. Thus, he declared: "I do not refute the National Consultative Assembly, and even I insist on its effective roles more than anybody else, because I have brought sufficient documents in this regard for all of our great scholars who reside in religious cities or abroad, and I now again insist on my stance. No scholar can reinstate that an assembly for resisting oppression and executing Islamic law is useless. The major problem is the presence of a couple of infidel liberate men who regard Islamic law as a barrier to their corruptive acts, and they only intend to prevent the Assembly from benefitting from Islamic law and Sharia". (Rezvani, 1983: 44-52).

While Constitutionalists had a positive attitude to the Constitutionalismand preferred it over despotism, Sheikh Fazlolah was highly fearful of the destruction of religious culture by the western-oriented Constitutionalists, thus he preferred the former dictatorship in which the kings would show respect for religious affairs even for outward appearance and for keeping a traditional society satisfied. Sheikh's jurisprudential argument was that: "practical resistance to the divine law is sin, and altering it is blasphemy" (Zargarinezhad, 1999: 180).

Sheikh Fazlollah reinstated that imperfect human reason is incapable of achieving the good and evil, and only God has right to perform such critical deed. In addition, he argues that the new man does not abide by the divine obligations and regulation because he desires to follow his eternal lusts, and utilizes humanitarian laws that are able to provide his passions. For this reason, today's man moves toward depravity and corruption. So his religious obligation-oriented approach which is in sharp contrast to freedom-oriented perspectives, encompasses not only private area but also public domains and political authority. According to Sheikh, in the early days of Islam, the duty of the Prophet was to express divine laws and their implementation. However, after this stage, the jurists as "public proxies" are responsible for accomplishing such heavy obligations "in order to execute rights and regulate codes" (Zargarinejad, 1998: 166). Therefore, Sheikh Fazlollah argues that "anybody other than the above-mentioned persons has not right to govern Muslim community and any support of him is unlawful and prohibited" (Torkman, 1983: 67, vol. 1).

Sheikh Fazlollah believed that all state affairs should be based on judgments and orders of the righteous scholars, even the "position of the government and its implementation must be conducted based on the rules issued by Islamic jurists rather than Department of Justice and the Police and other authorities" (Rezvani, 1983: 69). Therefore, he thought that "guardianship and obedience" and "permission and supervision" must be the responsibility of Mojtaheds. In his opinion, in Shia faith, in case the government office is held by any authority other than God and three other authorities namely the prophets, owlia (divine saints), the obedience to such government is not obligatory.

Sheikh Fazlollah's interpretation of the term "monarchy" was the same government in many cases, and he believed that "the monarchy is the executive power of Islamic rules". He would consider the philosophy underlying the formation of the state as the enforcement of the divine law, and argued that "Islamic rules have no effect" without political state and power (Zargarinejad, 1998: 164). He insisted on the fact that Islamic law is valid in all areas and for all ages, and according to Shi'ite beliefs, he would know jurists as executive powers in the community and was highly concerned about the implementation of the laws rather than the nature of laws and government. Thus, he opposed the separation of power in the society.

Either when he turned to the Constitutionalism or when he rejected it, Sheikh Fadlallah aimed to increase the power of the clergy with the aim of better implementation of religious laws. At the beginning of the Constitution, he concentrated on the principle that the Constitution's aim is to enforce the divine laws in the form of a new social system 
built upon council and turning it into a legal procedure (Derakhsheh, 2005: 89). By limiting the monarchy, he aimed to strengthen the status of the jurists for achieving executive positions, and to turn the King into a totally executive manager. However, after a while, he noticed that theConstitutionalism moves toward the advocates of the West in a different way. Thus, he began to criticize the Constitutionalists and also to defend the Monarchy in order to motivate the jurists to extract the divine rules and regulations, and then the King execute them, and receive his legitimacy from the clergy same as the past (Jahanbozorgi, 2002: 193-194).

\section{Conclusion}

Although it is possible to analyze dispute between the Constitutional Legitimist scholars from different aspects, the historical data show that the most important difference of them was their interpretation of the Constitutionalism. As the Constitutional scholars would consider the positive side of the Constitutionalismwhich was able to strengthen the authority of the clerics and religious values, they did not see any conflict between this trend and Islam, and they sought to underline the parts of Islam which was not in line with the Constitution. However, the Legitimists which would see the westernized side of the Constitutionalism and its secular-oriented stance emphasized those parts of Islam which would refute the Constitutionalism. The common point between the Constitutional Legitimist scholars was that both believed that at the era of the Occultation (or the messianic notion of the advent of the Mahdi where the legitimate ruler of Shiite nation is absent), the government would be the duty and the right of the clerics. In fact, in the past, as the historical and social conditions had estranged the clerics from the state, they would operate as the government overseers, and they suffice to protect Islam's ammunition only by formulating and interpreting religious laws as the dominant rules in the society. The Constitutionalists solution aimed to have more control over the government by an instrument so called the Constitutionalism. In contrast, the Legitimists believed that such ideal is not only highly unlikely but also can bring about worse aftermaths for the clerics and religion, and they must suffice to the former state. The Constitutionalists not only sought to resist tyranny, despotism and oppression, they were also aimed to spread religion, enforce law, execute canonic laws, and strengthen the authority of the clerics in social and political life. They localized the Theory of the Constitutionalism, and attempted to increase the religious concentration of the state as much as possible. In other words, they sought to infiltrate into the Parliament and so play more prominent roles in the area of government and authority, and oppose arbitrary and despotic rulers by ratifying laws based on the divine regulations. In an era when the penetration of new ideas had shaken the bases of the legitimacy of the monarchy, these scholars had prepared themselves to play a more prominent role in administering the country by means of the Constitutionalism.

However, the Legitimists which would consider the Western-oriented secular intellectuals as the main epochmaking powers of the Constitutionalisminterpreted the trend from another perspective. They believed that the aftermath of the Constitutionalismwould be weakening and undermining of the clerics and religious rules, and further fueling of the secularism. Therefore, they preferred the former political system which at least maintain previous position.

\section{References}

Abadiyan, H. 1995; The theoretical fundamentals of the Constitutional and Legitimist state; Tehran, NashrNai

Esfahani, N. A. 1993; Resident and traveler; Isfahan, Bina

Amiri, J., 2003. Intellectulasim and politic (intellectual developments in contemporary Iran); Tehran; Islamic Revolution Documents Center.

Tabrizi, M. H. B. A. Kashf al-Morad Men al-Mashrutava Al-Istebdad; Manuscript of the National Library, available at: http://dl.nlai.ir/Ul/62850b1d-0ff2-49c4-9ef3-01e0031cf0ea/LRRView.aspx

Torkman, M., 1983. Treatises, leaflets, documents, etc. and newspaper published by Sheikh FazlullahNuri, vol. 2, Tehran: Rasa Institute of Cultural Services

Jahanbozorgi, A., 2002. Introduction to the theory of evolution of government in Islam; Tehran, Islamic Thought and Culture Research Center

Derakhsheh, J., 2005; Shia political discourse in Contemporary Iran; Tehran; Imam Sadiq University

Rezvani, H., 1983. Bills of Agha Sheikh FazlullahNouri; Tehran; Tarikh Publications

Zargarinejad, H. 1998. Political thinking in Islam; translated by BahaoddinKhoramshahi; Tehran, Kharazmi Publications

Kasravi, A. 2537. Iran's Constitutional Law; vol. 1 \& 2; Tehran: Amir Kabir

Kamali, M. 2002. Civil society, government and modernization in contemporary Iran; Translated by Kamal Pouladi; Tehran. Center for Recognition of Islam and Iran

Lari, A. H. 1946. Legitimism and Constitutionalism Law; Shiraz; MohammadiShirazi Publication Center

Madani, J. 1990. The history of Iran's political developments and foreign relations, vol. 2, Qom, Islamic Publications Office.

Namdar, M., 1997. An approach to the ideological foundations of the Shiite political movements and schools in the last one hundred 
years; Tehran: Institute for Humanities and Cultural Studies.

Naeini, M. H., 1982. Tanbih al-Omah and Tanzih al-Melah; SahamiEnteshar; Tehran, Publication Center 